\title{
UNDERSTANDING LAND USE CHANGES IN THE CENTRAL HIGH-ANDEAN MOIST PUNA
}

\author{
SANTIAGO MADRIGAL-MARTÍNEZ ${ }^{1,2,3}$ \& JOSÉ LUIS MIRALLES I GARCÍA ${ }^{1 *}$ \\ ${ }^{1}$ Polytechnic University of Valencia, Valencia, Spain \\ ${ }^{2}$ Ricardo Palma University, Lima, Peru \\ ${ }^{3}$ La Molina National Agrarian University, La Molina, Peru
}

\begin{abstract}
Mountain ecosystems around the world are facing rapid land-cover changes, which have received much attention among scientists, managers, and policy-makers. A growing scientific production has been possible by free and open access data and the use of remote sensing and geographic information system tools. In this context, our study quantified the land-use changes across 25 provinces in the central high-Andean moist Puna over the interval of 13 years, using a selection of eleven land-use/cover types included in the standardized nomenclature of the Corine Land Cover for Peru. Thereafter, we determine the importance of social-economic driving factors in two time periods, from 2000 to 2009 and 2009 to 2013. The results described three spatial patterns: (1) a North-South division, (2) two different trends described by intensification/de-intensification agriculture, and (3) persistent forestland deterioration. Overall, our study reveals that agriculture in densely occupied provinces is the leading land-use change process negatively affecting pasture and forest extent. Moreover, understanding the spatial patterns of changes in the extent and their explanatory variables is important for clarifying land-use change trajectories. We hope our study will support spatial decision-making in complex mountain landscapes. Keywords: land use change, mountain ecosystem, spatial planning, GIS, high-Andean Puna, Peru.
\end{abstract}

\section{INTRODUCTION}

The most important human induced environmental impacts have become recognized as a consequence of changes in land-cover and land-use [1]. These rapid land-cover changes occurred around the world have received much attention from scientists and there were numerous studies focused on various research issues at different spatial scales [2]-[5]. This growing scientific production has been possible by free and open access data [6] and the use of remote sensing and geographic information system (GIS) tools [7]. GIS provides a flexible environment for a rapidly developing data processing and analysing for change detection in a study area. In high-Andean mountains, most previous land-use change studies using GIS focused on a peri-urban interface [8], [9], or a watershed [10]-[14], or a specific ecosystem [15]-[18], but not much research has been done across multiple provincial boundaries. In Peru, land planning at local level is regulated by provincial municipalities (Organic Law of Municipalities No. 27972, 27 of May of 2003), these could benefit from land-use research and improve management purposes and decision-making. To the best of our knowledge, there are no land-use change studies at provincial scale across high-Andean highlands.

In this context, this paper is focusing in a sector of the Peruvian high-Andean mountains, the central moist Puna $\left(64,025 \mathrm{~km}^{2}\right)$, comprised within the administrative boundaries of 25 provinces in the departments of Junín, Huancavelica and Ayacucho (Fig. 1). Provincial area ranged from 724 to $10,999 \mathrm{~km}^{2}$ with an average of $2561 \mathrm{~km}^{2}$. These provinces define a highly populated mountain ecosystem (population at the end of 2017 was 2096,156 [19]) that has been occupied and its resources profited during several millennia by Andean civilizations [20], [21]. Its main social-ecosystems consist of natural grassland, shrubland and agricultural

*ORCID: http://orcid.org/0000-0001-5638-2608 
areas [21], that are threatened by human activities [22], as agricultural intensification, grasslands extent, afforestation and urbanization [23].

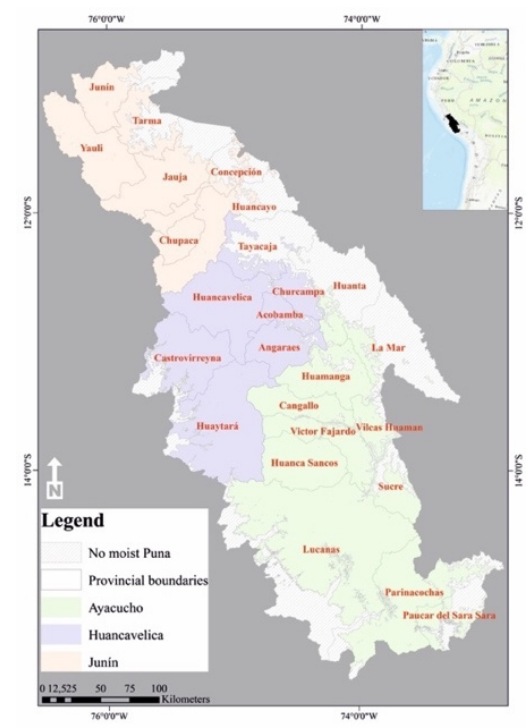

Figure 1: Central high-Andean moist Puna.

The study quantified the land-use changes at provincial scale across the central high-Andean moist Puna over the interval of 13 years, from 2000 to 2013, using a selection of eleven land use/cover (LULC) types included in the standardized nomenclature of the Corine Land Cover (CLC) for Peru. The LULC units include two classes related to artificial surfaces (continuous urban fabric and mineral extraction sites), one unit that is matched to agricultural areas, seven attributes associated to forests and semi-natural areas (low forest, forest plantation, natural grassland, shrublands, bare rock, sparsely vegetated areas and glaciers), one item linked to wetlands (peatbogs and high-Andean wetlands) and, finally, two categories linked to water bodies (water courses and water bodies). In a second step, we determine the importance of social-economic driving factors in two-time periods, from 2000 to 2009 and 2009 to 2013 . The factors considered were related to population growth, economic development and technological progress.

Finally, the work detailed in this paper address the first objective of a $\mathrm{PhD}$ thesis and resolve the following aim questions: (1) Which are the main anthropogenic land-use changes? (2) Which are the significant social-economic drivers that explain land-use changes? We hope our results will support spatial decision-making in the high-Andean region. In addition, our findings can provide a reference for studies in complex mountain landscapes.

\section{METHODS}

\subsection{Identification of land use/cover units}

The identification of the 11 representative high-Andean moist Puna LULC units included in the standardized nomenclature of the Corine Land Cover (CLC) for Peru was achieved from three sources, the map of high-Andean ecosystems from 2000 [24], the official flora cover 
map from 2009 [25] and the official flora cover map from 2013 [26]. These are polygon shapefiles generated in a mapping scale of 1:100,000 with Landsat (TM) images. Table 1 shows the harmonization of the three-time step features to obtain the moist Puna LULC units.

Table 1: Land use/cover units resulting from the features of the three-time step data.

\begin{tabular}{|c|c|c|c|}
\hline $\begin{array}{l}\text { CLC } \\
\text { code }\end{array}$ & LULC units & Features & $\begin{array}{l}\text { Data } \\
\text { Source } \\
\end{array}$ \\
\hline \multirow[b]{2}{*}{ 1.1.1. } & \multirow[b]{2}{*}{$\begin{array}{l}\text { Continuous urban } \\
\text { fabric }\end{array}$} & - Cities and settlements & (1) [24] \\
\hline & & - Urban area & $\begin{array}{l}\text { (2) }[25] \\
\text { (3) }[26]\end{array}$ \\
\hline \multirow{3}{*}{2.} & \multirow{3}{*}{ Agricultural areas } & - Human at work areas & $(1)$ \\
\hline & & - Crops & $(2)$ \\
\hline & & - Andean agriculture & (3) \\
\hline \multirow{3}{*}{ 3.1.1. } & \multirow{3}{*}{ Low forest } & $\begin{array}{l}\text { - Inter-Andean xeric montane forest and } \\
\text { shrublands } \\
\text { - Low high-Andean forest } \\
\text { - High-montane low forest and shrublands }\end{array}$ & $(1)$ \\
\hline & & $\begin{array}{l}\text { - Queñoal } \\
\text { - Inter-Andean xeric forest }\end{array}$ & $(2)$ \\
\hline & & $\begin{array}{l}\text { - Inter-Andean xeric forest } \\
\text { - High-Andean relict forest } \\
\text { - Meso-Andean relict forest } \\
\end{array}$ & (3) \\
\hline \multirow{3}{*}{3.2.} & \multirow{3}{*}{ Forest plantation } & - Human at work areas & $(1)$ \\
\hline & & - Afforestation & $(2)$ \\
\hline & & $\begin{array}{l}\text { - Forest plantation (pinus and eucalyptus } \\
\text { species) }\end{array}$ & (3) \\
\hline \multirow{2}{*}{ 3.3.1. } & \multirow{2}{*}{ Natural grassland } & $\begin{array}{l}\text { - High-Andean grassland } \\
\text { - High-montane grassland }\end{array}$ & $\begin{array}{l}\text { (4) [27] } \\
(3) \\
\end{array}$ \\
\hline & & $\begin{array}{l}\text { - High-Andean grassland } \\
\text { - Puna grass }\end{array}$ & $(2)$ \\
\hline \multirow[t]{2}{*}{ 3.3.2. } & \multirow[t]{2}{*}{ Shrublands } & $\begin{array}{l}\text { - Inter-Andean xeric montane shrublands } \\
\text { - Inter-Andean xeric shrublands } \\
\text { - High-montane shrublands } \\
\text { - High-Andean shrublands }\end{array}$ & (1) \\
\hline & & - Shrublands & $(2) ;(3)$ \\
\hline \multirow{2}{*}{ 3.4.3. } & \multirow{2}{*}{$\begin{array}{l}\text { Sparsely vegetated } \\
\text { areas }\end{array}$} & - Tundra & $(4) ;(2)$ \\
\hline & & - High-Andean areas with rare vegetation & $(2) ;(3)$ \\
\hline \multirow{2}{*}{ 3.4.5. } & \multirow{2}{*}{ Glaciers } & - Nival & $(1)$ \\
\hline & & - Glaciers & $(2) ;(3)$ \\
\hline 4.1.2. & $\begin{array}{l}\text { Peatbogs and high- } \\
\text { Andean wetlands }\end{array}$ & - High-Andean wetlands & $\begin{array}{l}(1) ;(2) ; \\
(3)\end{array}$ \\
\hline \multirow{2}{*}{5.1 .1} & \multirow{2}{*}{ Water courses } & - Water bodies & $(1)$ \\
\hline & & - River & $(2) ;(3)$ \\
\hline \multirow{2}{*}{ 5.1.2. } & \multirow{2}{*}{ Water bodies } & - Water bodies & (1) \\
\hline & & - Lagoons and lakes & $(2) ;(3)$ \\
\hline
\end{tabular}


Some limitations were detected in the map of high-Andean ecosystems. It has a vague delimitation for two land units (agricultural areas and forest plantation) comprehending them in only one land-use category (human at work areas). This limitation was clarified using the detailed land-use types from the two official flora cover maps. Another constraint was found in natural grassland and sparsely vegetated areas, these were better defined when utilised the data from the official Peruvian forest map [27].

\subsection{Analysing spatial land-use change in the central moist Puna}

Land-use changes between 2000 and 2013 were calculated by means of a transition matrix obtained after using ArcGIS 10.3 [28]. The matrices of land-use transition were established for two-time periods, including 2000-2009 and 2009-2013. Each transition matrix gathered the quantity of land that was converted from each LULC unit to any other or units that remain unchanged in the study periods. Changes of interest in this study were related to agricultural areas, grassland extent and forestland size. These variations were further calculated obtaining increased/decreased extents. Next, to measure and compare the intensity of land-use changes between provinces, proportion of area increase and extent decrease (of the chosen classes) were calculated for the two-time periods. The following formula was used to calculate the index for area increase (1) and for area decrease (2):

$$
\begin{gathered}
\mathrm{Pi}_{\mathrm{n}}=\frac{\mathrm{LULC}_{\mathrm{nt} 2}}{\mathrm{AT} T_{\mathrm{n}}}, \\
\mathrm{Pd}_{\mathrm{n}}=\frac{\left(\mathrm{LULC}_{\mathrm{nt} 2}\right)_{\mathrm{n} 1}-L U L C_{\mathrm{n} 1}}{\mathrm{AT} T_{\mathrm{n}}},
\end{gathered}
$$

where $\mathrm{LULC}_{\mathrm{nt} 2}$ is the new area $\left(\mathrm{km}^{2}\right)$ of the chosen class in a province $n$ at the final year $t 2$; $\left(\mathrm{LULC}_{\mathrm{nt2}}\right)_{\mathrm{nt1}}$ is the overlapping area of a given class in both years; $\mathrm{LULC}_{\mathrm{nt} 1}$ is the area $\left(\mathrm{km}^{2}\right)$ of the chosen class in a province $n$ at the initial year $t 1 ; \mathrm{AT}_{\mathrm{n}}$ is the total area of the province $n$. This index gave a relative measure of the change that was ranked in five levels of equal intervals representing the intensity of expansion/contraction of each chosen class at provincial scale. Furthermore, we performed Pearson's correlation $\left(r_{p}\right)$ to assess the pairwise relations between LULC categories for the two-time periods at provincial scale, using R [29].

\subsection{Determining the explanatory capacity of social-economic drivers}

Redundancy analysis (RDA) was computed to determine the importance and capacity of social-economic drivers for predicting the land-use changes during the two-time periods. RDA was calculated using the "vegan" R package and the function "ordistep" [29], after 10,000 permutations [30]. The drivers considered were related to population growth, economic development and technological progress (Table 2).

Table 2: Factors, specific drivers and proxies used for predicting land-use changes.

\begin{tabular}{|llll|}
\hline Factor & Driver & Proxy & Unit \\
\hline $\begin{array}{l}\text { Population } \\
\text { growth }\end{array}$ & $\begin{array}{l}\text { Population } \\
\text { density }\end{array}$ & $\begin{array}{l}\text { Log average of population } \\
\text { density (for each period) }\end{array}$ & People $/ \mathrm{km}^{2}$ \\
\hline $\begin{array}{l}\text { Economic } \\
\text { development }\end{array}$ & Income & $\begin{array}{l}\text { Net annual income per family } \\
\text { (averaged for each period) }\end{array}$ & S/year \\
\hline $\begin{array}{l}\text { Technological } \\
\text { progress }\end{array}$ & Education & $\begin{array}{l}\text { Population with completed } \\
\text { secondary school education } \\
\text { (averaged for each period) }\end{array}$ & $\%$ \\
\hline
\end{tabular}


These variables were selected due to their role as anthropogenic drivers of ecosystem change [31] and data availability. Information from public census statistics [19] were used to quantify each variable.

\section{RESULTS}

\subsection{Changes in the extent of land use/cover categories}

Fig. 2(a) shows the spatial distribution of LULC categories across central Moist Puna from 2000 to 2013 . The dominant category is natural grassland that is spatially dispersed covering more than $60 \%$ of the territory in each year (Fig. 2(b)). The second major LULC type was shrubland, covering more than $15 \%$ of the entire area in each year, and mainly located in the south-west it exhibited a transitional zone between the moist Puna and the Peruvian Pacific desert. The third major LULC type was agricultural area with $8 \%$ of the landscape in 2000 and top with $12 \%$ in 2009 , mostly associated to the provinces that form Mantaro watershed. Sparsely vegetated areas and high-Andean wetlands occupied around $6 \%$ of the territory each year, covering central and northern areas. Low forest extent reduced from $3 \%$ to $1 \%$ during the time period, showing a slight aggregation effect with cropland extent. Water bodies and glaciers (only in 2000) represent $1 \%$ of the landscape, this last category is spatially associated with sparsely vegetated areas. There were only small amounts of urban lands, forest plantations and water courses covering less than $1 \%$ separately.

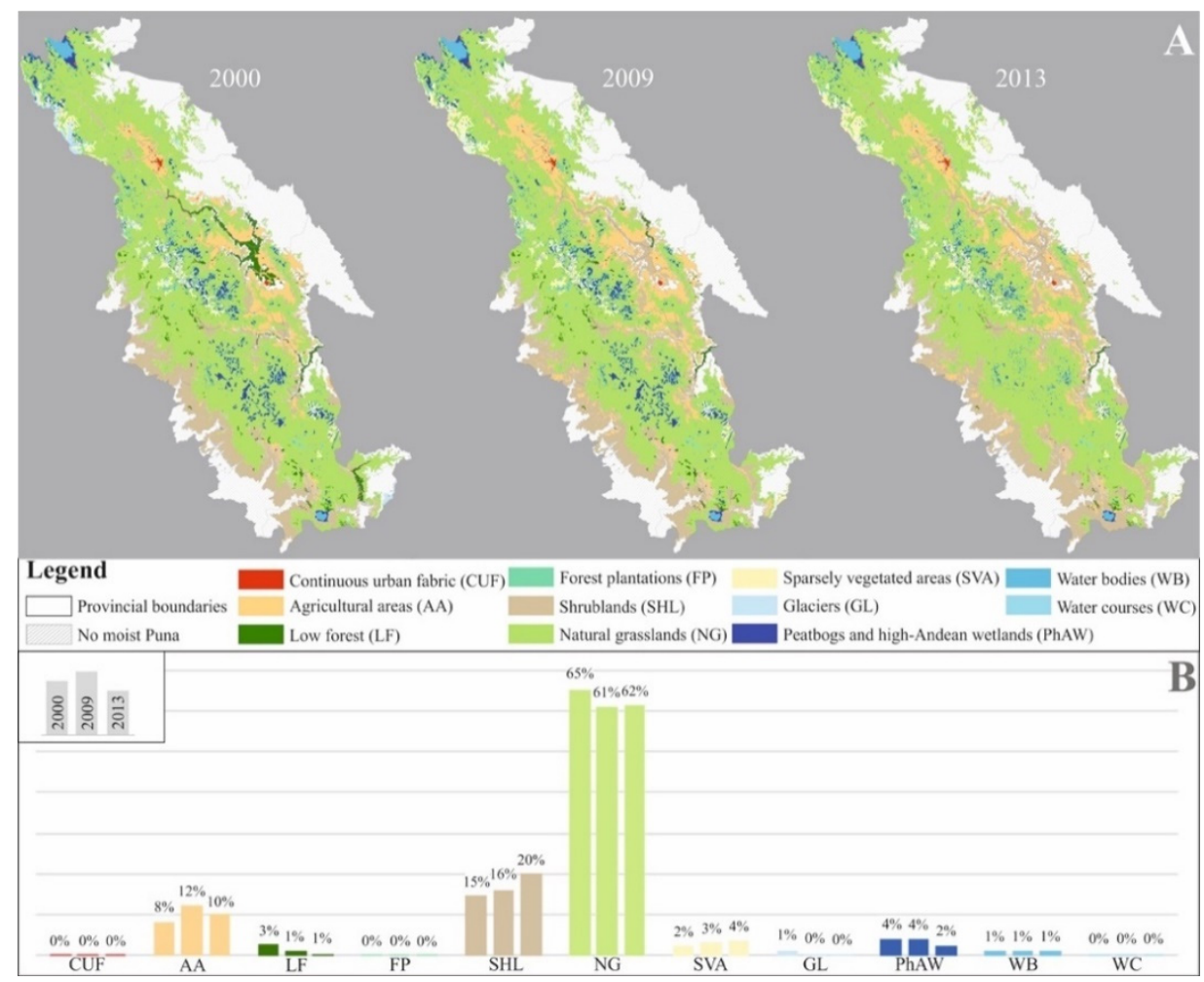

Figure 2: (a) Spatial distribution of land use/cover categories; and (b) Barplots showing the proportion of land of each category, in central moist Puna across time. 
Table 3 presents the transition matrix between 2000 and 2009 in central Moist Puna. The overall agreement (percentage of coinciding area, under equal LULC class) among the comparative maps was $92 \%$. Of the $8 \%$ of land-use change, $4.2 \%$ disturbed the chosen LULC categories. Agricultural areas increased by about 53.1\%, mainly as a result of the encroachment of natural grasslands and shrublands in that order, whereas had a reduction of $233.6 \mathrm{~km}^{2}$ after land abandonment. Low forest reduced by $60.2 \%$, largely replaced by shrublands following a forest degradation process, whereas experimented a slight recovery process $\left(20.8 \mathrm{~km}^{2}\right)$ due to colonisation of shrublands and agricultural land. Natural grasslands decreased around $2700 \mathrm{~km}^{2}$ principally by expanding agricultural frontier, but had a minor augmented due to glaciers retreat and dried up of high-Andean wetlands $\left(108 \mathrm{~km}^{2}\right)$.

Table 3: Transition matrix showing land-use changes of interest (in square kilometres) and change ratio occurred between 2000 and 2009 in central Moist Puna.

\begin{tabular}{|l|c|c|c|c|c|c|}
\hline 2009 & 2. & 3.1 .1$. & 3.3 .1$. & Other & Total & $\begin{array}{c}\text { Change } \\
(\%)^{*}\end{array}$ \\
\cline { 1 - 7 } 2000 & 4881.4 & 16.3 & 2400 & 556.2 & 7853.9 & 53.1 \\
\hline 2. & 10.6 & 677.5 & 4.4 & 10.2 & 702.7 & -60.2 \\
\hline 3.1 .1$. & 233.6 & 2.1 & 38656.9 & 108 & 39006 & -6.6 \\
\hline 3.3 .1$. & 4.3 & 1069 & 693.8 & 14701.2 & 16468.3 & 7.1 \\
\hline Other & 5129.9 & 1764.9 & 41755.1 & 15375.6 & 64025.5 & \\
\hline Total & 512.1. & Natural \\
\hline
\end{tabular}

Table 4 introduces the transition matrix between 2009 and 2013 in central Moist Puna. The overall agreement among the comparative maps was $91.8 \%$. Of the $8.2 \%$ of land-use change, $2 \%\left(1317 \mathrm{~km}^{2}\right)$ disturbed the chosen LULC categories. Agricultural extent decreased by about $17.7 \%$, mainly as a result of land abandonment $\left(2099.4 \mathrm{~km}^{2}\right)$, whereas had a growth of $542 \mathrm{~km}^{2}$ at the expenses of grassland. Low forest (reduced by $47.5 \%$ ) continued under a degradation process also identified in the preceding time period. Natural grasslands increased by $0.8 \%\left(300 \mathrm{~km}^{2}\right)$ principally by farming de-intensification and the persistent dried up process of high-Andean wetlands.

Table 4: Transition matrix showing land-use changes of interest (in square kilometres) and change ratio occurred between 2009 and 2013 in central Moist Puna.

\begin{tabular}{|l|c|c|c|c|c|c|}
\hline 2013 & 2. & 3.1 .1$. & 3.3 .1$. & Other & Total & $\begin{array}{c}\text { Change } \\
(\%)^{*}\end{array}$ \\
\cline { 1 - 7 } 2009 & 5754.2 & 8.1 & 542 & 160.5 & 6464.8 & -17.7 \\
\hline 2. & 0 & 369.1 & 0 & 0 & 369.1 & -47.5 \\
\hline 3.1 .1$. & 168 & 37457.8 & 1081.3 & 39306.5 & 0.8 \\
\hline 3.3 .1$. & 599.4 & 157.5 & 1006.2 & 15221.1 & 17885.1 & 8.7 \\
\hline Other & 1500.3 & 15.7 & 64025.5 & \\
\hline Total & 7853.9 & 702.7 & 39006 & 16462.9 & 6.1. Natural \\
\hline
\end{tabular}


Fig. 3 on the top row illustrates the intensity of land increase/decrease from 2000 to 2009 across the 25 provinces in central moist Puna. In this initial-time period, central moist Puna described a territory with a tendency to increase cropland areas and to decrease pasture and forestland extents. There are six provinces with a high intensity level and twelve with medium strength level, affected by agricultural area increase, pasture area decrease and forest extent decline. However, most of the provinces had very low proportion of change (32\%) or no change (41\%) denoting undisturbed areas primarily related to cropland extent decrease, grassland area increase and forestland extent increase.

At LULC category level, spatial distribution shows that increase in cropland extent (Fig. 3(a)) was related to decrease in pasture area (Fig. 3(d)), validated by a strong negative correlation $\left(\mathrm{r}_{\mathrm{p}}=-0.96839901\right.$ and $\mathrm{P}$-value $\left.<0.001\right)$. In the same way, reduction of agricultural areas (Fig. 3b) corresponded with the expansion of pasture lands (Fig. 3(c)) proving a negative relationship $\left(\mathrm{r}_{\mathrm{p}}=-0.6321261\right.$ and $\mathrm{P}$-value $\left.<0.001\right)$. Forestland extent increase (Fig. 3(e)) occurred with slight force (1.8\% of proportion of land-change) in one province (Churcampa), whereas forest area decreased (Fig. 3(f)) in 12 provinces (half of the territory), but intensely focussed in four jurisdictions. Pairwise relation between goals and losses of forest class presented a moderate negative correlation $\left(r_{p}=-0.4194168\right.$ and P-value $\left.<0.05\right)$. Whereas very slight negative relation was found between forestland decrease and crops increase $\left(r_{p}=-0.3497234\right.$ and $\mathrm{P}$-value $\left.<0.1\right)$, even so, two strongly deforested provinces $(19 \%$ for Acobamba and $8.3 \%$ for Angaraes) developed an important growth of farming activity (15\% for Acobamba and $9.4 \%$ for Angaraes).

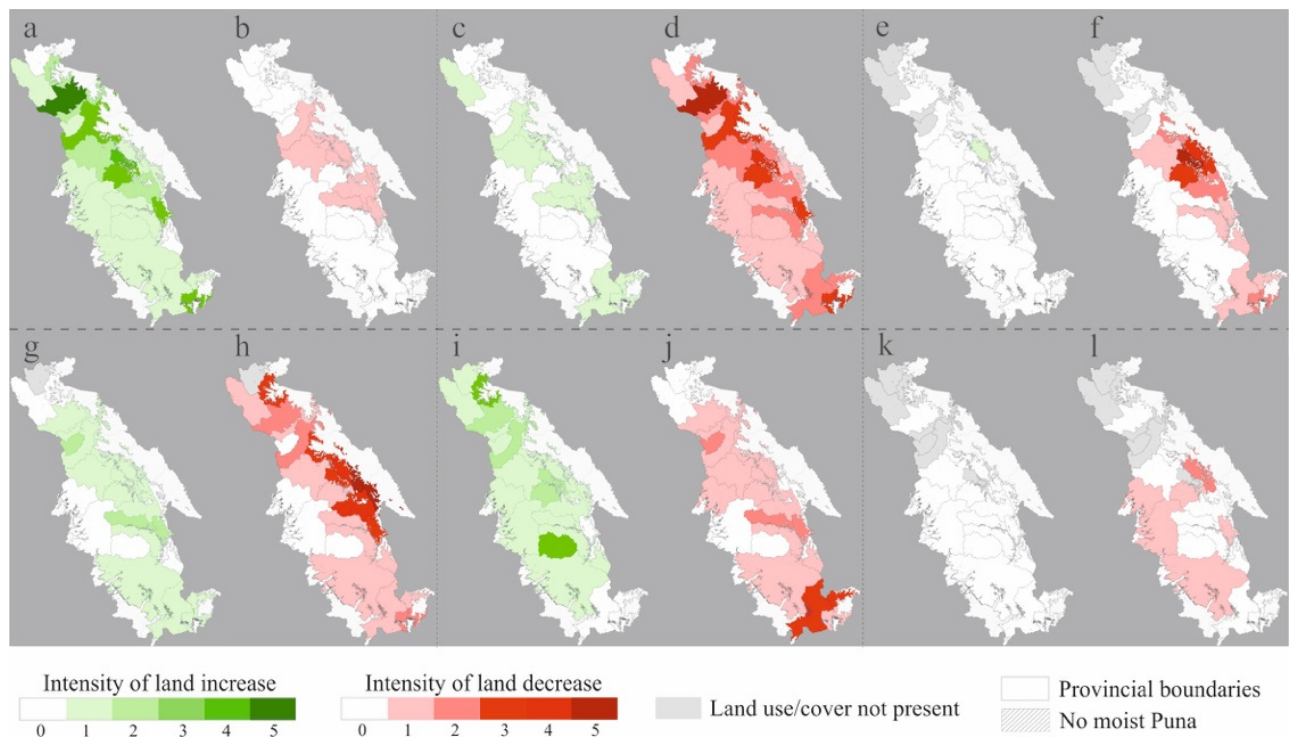

Figure 3: Land increase/decrease intensity of the chosen land use/cover categories at provincial scale in central Moist Puna. Top row: maps for the period 2000 and 2009. Bottom row: maps for the period 2009 and 2013. (a), (b), (g), (h) Agricultural area; (c), (d), (i), (j) Natural grassland extent; and (e), (f), (k), (l) Forestland extent. Ranks of intensity: 0 (no change), 1 (|>0-3.8\%|), 2 (|>3.87.6\%|), 3 (|>7.6-11.4\%|), 4 (|>11.4-15.2\%|), 5 (|>15.2-19.0\%|). 
Fig. 3 on the bottom row shows the intensity of land increase/decrease from 2009 to 2013 across the 25 provinces in central moist Puna. In this final-time period, forestland extent continued declining, grassland extent stayed balanced and agricultural areas inclined negatively. Despite this land-use changes, the territory continued, as initial-time period, dominated by areas with very low proportion of change (39\% of the provinces) or with no change (33\% of the provinces). However, there were strong variations registered in eight provinces due to cropland extent decrease.

At LULC category level, Fig. 3(g) and Fig. 3(j) captured similar spatial distribution between provinces affected by cropland extent increase and pasture area decrease, confirming a negative correlation $\left(\mathrm{r}_{\mathrm{p}}=-0.5596783\right.$ and P-value $\left.<0.01\right)$. On the contrary, as can be seen from the Fig. 3(i) and Fig. 3(h), enlargement of grassland extent had no significant relation $\left(r_{p}=-0.0352285\right.$ and $\mathrm{P}$-value $\left.=0.8672\right)$ with reduction of agricultural areas. Whereas forestland extent declined (Fig. 3(1)) with very low intensity in seven provinces that were positively interrelated to cropland size decrease $\left(\mathrm{r}_{\mathrm{p}}=0.4883865\right.$ and $\mathrm{P}$-value $\left.<0.05\right)$. It should be noted that no forest area increase was assessed in the final period (Fig. 3(k)).

\subsection{Capacity and importance of drivers to predict the distribution of individual land-use changes}

Each explanatory variable displayed different spatial distribution within the study area (Fig. 4). Population density varied slightly between both periods, characterising a territory with eleven provinces in a growing rate and fifteen provinces with a declining proportion over time. Income driver showed rather similar values for all the provinces, except for three provinces, Huamanga and Huancayo that include a major city each, and Yauli characterised by mining development. Education presented provinces of Junin with a higher percentage of people with completed secondary school than the provinces of Ayacucho and Huancavelica.

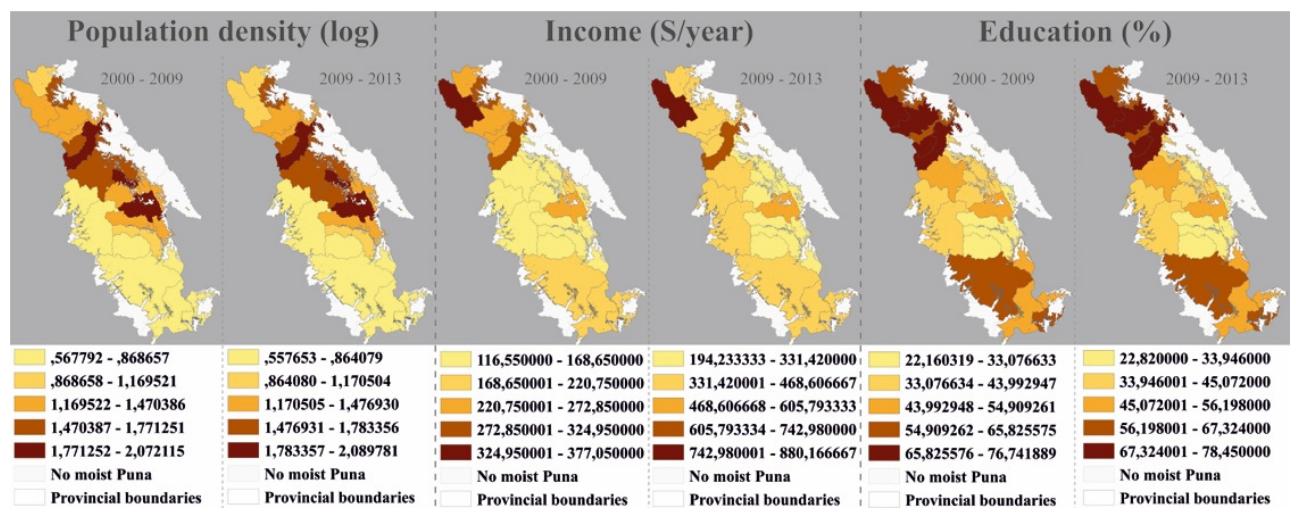

Figure 4: Spatial distribution of each driver for both time periods. The values of drivers are organised in equal interval quintiles.

There were disparities regarding how well the drivers predicted individual land-use changes (Fig. 5(a)). Changes in area decrease were better predicted in agricultural area (both periods), forestland extent (2000-2009) and natural grassland extent (2000-2009), in that order. Natural grassland decrease (2009-2013), forestland extent decrease (2009-2013) and 
all changes in area increase were poorly predicted by all three drivers. Overall, our results show that variations of cropland extent were the best explained.

The function "ordistep" of redundancy analysis showed that the significance to predict land-use changes was shared among variables, and that different land-use changes were best predicted by different variables (Fig. 5(b)). Population density was the best driver showing its importance for predicting cropland area changes (both periods), forestland and pasture extent decrease (2000-2009). Income did well predicting forestland extent decrease during 2000-2009, and education did well explaining agricultural area decrease in both time-steps. No variables predicted natural grassland decrease (2009-2013) and increase (both periods), forestland extent decrease (2009-2013) and increase (2000-2009). Overall, drivers had best significance clarifying changes in the first-time period.

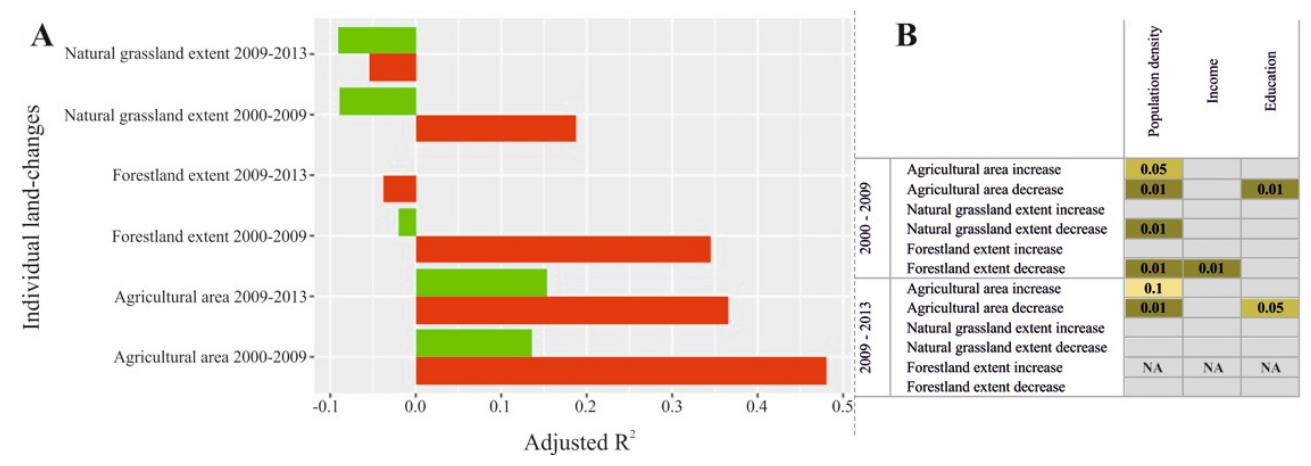

Figure 5: (a) Capacity of drivers to predict the distribution of individual land-use changes for the two-time periods (green horizontal barplots are relate to LULC area increase; red horizontal barplots are relate to LULC area decrease); and (b) Importance of each driver for predicting individual land-changes for the twotime periods (boxes with P-value of significant relationship are coloured; darker colours indicate a strong correlation; grey boxes indicate no significance).

\section{DISCUSSION AND CONCLUSION}

This study analysed spatial patterns of land-use change occasioned by human activities in central high-Andean moist Puna since 2000. The results described three patterns: (1) a North-South division in terms of land-use change intensity over time, (2) two spatially different trends of intensifying agriculture during 2000-2009 and de-intensification during 2009-2013, negatively correlated to natural grassland extent, and (3) a persistent negative trend of forestland area over time and across space. Moreover, the observed land-use change trends were predicted by explanatory variables based on publicly available data.

The first spatial pattern identified a North-South divide in terms of land-use change intensity that was primarily related to population growth factor (Figs 4 and 5(b)). Northern side of the moist Puna was characterised by high intensity levels of land increase/decrease in each chosen LULC type (Fig. 3). Most of these provinces are located in the Mantaro river basin characterised by fertile lowlands and high population density (especially in the surrounding areas of the two major cities, Huancayo and Ayacucho). On the contrary, the South sector represented by larger desolate highland extents showed a prevalent very low proportion of area change (Fig. 3). These results agree with similar findings in the Andes that remarked the driven role of high population density predicting agricultural intensification [8], 
[32], while isolated rural communities have little motivation to advance in their land beyond subsistence farming [33].

The second important pattern assessed in central high-Andean moist Puna was described by two trajectories concerning cropland extent. The first trend described a process of agricultural intensification predicted by population growth during 2000-2009 (Figs 3(a) and 4). This period was characterised by an internal migration highly occurred in the Mantaro Valley's that promoted the rapid growth of commercial farming in the lowlands [34], [35]. Whereas, the second trend showed farming land decrease during 2009-2013 linked to high population density and low schooling percentage (Fig. 5(b)). Fonte et al. [36] and Skarbø and VanderMolen [37] confirmed that population increase result in soil degradation pushing farmers to crop higher elevations with more favourable conditions. In the same way, Agudelo-Patiño and Miralles-Garcia [38] reported that the city growth shifted agricultural peri-urban systems in an Andean metropolitan area.

The third spatial pattern showed a trajectory of forestland extent decrease over the two-time steps and across half of provinces in the central moist Puna primarily defined by high population density, low family income and education (Fig. 4). Forest area degraded (replaced by shrublands) more intensely during 2000-2009 (Fig. 3(f)), mainly caused by overgrazing and controlled burning, which are principal drivers assessed in previous work [20], [39], [40]. Although deforestation provinces were correlated to agricultural expansion, not represented an important process, contrary to global study findings [40], [41]. On the other hand, during 2009-2013, few provinces had a forest decline not well explained by low population density and middle percentage of adults with complete secondary school.

In that sense, although our research focused on causal factors of the land-use change, there is a lack for explaining the observed spatial patterns that suggest further assessment. However, we presented a transparent approach about spatial patterns of land-use changes in in the moist Puna that can contribute to a better understanding of complex social-ecological mountain landscapes. Understanding the spatial patterns of changes in the extent and their explanatory variables, is important for clarifying land-use change trajectories. Therefore, typifying land-use change dynamics of the moist Puna would be a beneficial and interesting field for future research. Moreover, our study could be used as starting point for the development of research focusing on the impact of the land-use change patterns on biodiversity and ecosystem services.

\section{REFERENCES}

[1] Turner, B.L., Toward integrated land-change science: Advances in 1.5 decades of sustained international research on land-use and land-cover change. Challenges of a Changing Earth. Global Change - The IGBP Series, eds W. Steffen, J. Jäger \& D.J. Carson, BC Springer: Berlin and Heidelberg, pp. 21-26.

[2] Egarter Vigl, L. et al., Using land use/land cover trajectories to uncover ecosystem service patterns across the Alps. Reg Environ Chang, 17, pp. 2237-2250, 2017.

[3] Kuemmerle, T. et al., Hotspots of land use change in Europe. Environ Res Lett, 11(064020), 2016.

[4] Du, X. et al., Spatial pattern of land use change and its driving force in Jiangsu province. Int J Environ Res Public Health, 11, pp. 3215-3232, 2014.

[5] Lee, E. et al., Land cover change explains the increasing discharge of the Paraná River. Reg Environ Chang, 18, pp. 1871-1881, 2018.

[6] Wulder, M.A. et al., Land cover 2.0. Int. J. Remote Sens, 39, pp. 4254-4284, 2018.

[7] Lu, D. et al., Change detection techniques. Int J Remote Sens, 25, pp. 2365-2407, 2004. 
[8] Haller, A., Vivid valleys, pallid peaks? Hypsometric variations and rural-urban land change in the Central Peruvian Andes. Appl Geogr, 35, pp. 439-447, 2012.

[9] Rubiano, K. et al., Secondary forest and shrubland dynamics in a highly transformed landscape in the Northern Andes of Colombia (1985-2015). Forests, 8, Epub ahead of print 2017. DOI: 10.3390/f8060216.

[10] Anselm, N., Brokamp, G. \& Schütt, B., Assessment of land cover change in Peri-Urban high Andean environments south of Bogotá, Colombia. Land, 7, p. 75, 2018.

[11] Molina, A. et al., Multidecadal change in streamflow associated with anthropogenic disturbances in the tropical Andes. Hydrol. Earth Syst. Sci., 19, pp. 4201-4213, 2015.

[12] Saavedra Briones, P. \& Sepúlveda-Varas, A., systematic transitions in land use and land cover in a pre-Andean sub-watershed with high human intervention in the Araucania region, Chile. Cienc. e Investig. Agrar., 43, p. 6, 2016.

[13] Restrepo, J.D., Kettner, A.J. \& Syvitski, J.P.M., Recent deforestation causes rapid increase in river sediment load in the Colombian Andes. Anthropocene, 10, pp. 13-28, 2015.

[14] Gutiérrez, B.N. et al., The recovery of the lower montane cloud forest in the Mucujún watershed, Mérida, Venezuela. Reg. Environ. Chang., 13, pp. 1069-1085, 2013.

[15] Quintero-Gallego, M.E., Quintero-Angel, M. \& Vila-Ortega, J.J., Exploring land use/land cover change and drivers in Andean mountains in Colombia: A case in rural Quindío. Sci. Total Environ., 634, pp. 1288-1299, 2018.

[16] Miranda, A. et al., Different times, same story: Native forest loss and landscape homogenization in three physiographical areas of south-central of Chile. Appl Geogr, 60, pp. 20-28, 2015.

[17] Tovar, C., Seijmonsbergen, A.C. \& Duivenvoorden, J.F., Monitoring land use and land cover change in mountain regions: An example in the Jalca grasslands of the Peruvian Andes. Landsc. Urban Plan, 112, pp. 40-49, 2013.

[18] Ektvedt, T.M., Vetaas, O.R. \& Lundberg, A., Land-cover changes during the past 50 years in the semi-arid tropical forest region of northern peru. Erdkunde, 66, pp. 57-75, 2012.

[19] INEI (National Institute of Statistics and Informatics), National census. www.inei.gob.pe/estadisticas/censos/.

[20] Josse, C. et al., Ecosistemas de los Andes del Norte y Centro; Secretaría General de la Comunidad Andina, Programa Regional ECOBONA-Intercooperation, CONDESANProyecto Páramo Andino, Programa BioAndes, EcoCiencia, NatureServe, IAvH, LTA-UNALM, ICAE-ULA, CDC-UNALM, RUMBOL SRL, Lima, pp. 7-9, 2009. www.saber.ula.ve/handle/123456789/39336. Accessed on: 19 Sep. 2018.

[21] Young, K.R., Andean land use and biodiversity: Humanized landscapes in a time of change. Ann Missouri Bot Gard, 96, pp. 492-507, 2009.

[22] Millenium Ecosystem Assessment Board, Ecosystems and human well-being: Synthesis report, 2005. www.islandpress.org. Accessed on: 20 Sep 2018.

[23] Lambin, E.F., Geist, H.J. \& Lepers, E., Dynamics of land-use and land-cover change in tropical regions. Annu. Rev. Environ. Resour., 28, pp. 205-241, 2003.

[24] Josse, C. et al., Mapa de ecosistemas de los andes del norte y centro. Bolivia,Colombia, Ecuador, Perú y Venezuela, Lima, 2009.

[25] Ministry of Environment, Memoria descriptiva del mapa de cobertura vegetal del Peru. Lima, Peru, 2012.

[26] Ministry of Environment. Mapa nacional de cobertura vegetal. Memoria descriptiva, Lima, 2015. www.minam.gob.pe/patrimonio-natural/wp-content/uploads/sites/6/ 
2013/10/MAPA-NACIONAL-DE-COBERTURA-VEGETAL-

FINAL.compressed.pdf. Accessed on: 18 Nov. 2018.

[27] National Institute of Natural Resources, Mapa forestal del Perú. vol. 1, 2000.

[28] ESRI, ArcGIS Desktop: Release 10.3, Environmental Systems Research Institute, 2014.

[29] R Development Core Team, R: A language and environment for statistical computing. R Foundation for Statistical Computing, 1, p. 409, 2016.

[30] Legendre, P. \& Legendre, L.F., Numerical Ecology, Elsevier, 2012.

[31] Nelson, G.C. et al., Anthropogenic drivers of ecosystem change: An overview. Ecology and Society, 11, p. 29, 2006.

[32] Caycho-Ronco, J. et al., Tecnologías sostenibles y su uso en la producción de papa en la región altoandina. Rev Latinoam la Papa, 15, pp. 20-37, 2009.

[33] Swinton, S.M. \& Quiroz, R., Poverty and the deterioration of natural soil capital in the Peruvian altiplano. Environment, Development and Sustainability, Kluwer Academic Publishers, pp. 477-490.

[34] Stepputat, F. \& Nyberg Sørensen, N., The rise and fall of 'Internally Displaced People' in the Central Peruvian Andes. Dev Change, 32, pp. 769-791, 2001.

[35] Haller, A. \& Borsdorf, A., Huancayo Metropolitano. Cities, 31, pp. 553-562, 2013.

[36] Fonte, S.J. et al., Pathways to Agroecological intensification of soil fertility management by smallholder farmers in the Andean Highlands. Advances in Agronomy, pp. $125-184$.

[37] Skarbø, K. \& VanderMolen, K., Maize migration: key crop expands to higher altitudes under climate change in the Andes. Clim. Dev., 8, pp. 245-255, 2016.

[38] Agudelo-Patiño, L.C. \& Miralles-Garcia, J.L., Design and management of the metropolitan green belt of Aburrá Valley, Colombia. WIT Transactions on Ecology and the Environment, WIT Press: Southampton and Boston, vol. 194, pp. 193-203, 2015.

[39] Fjeldså, J., Polylepis forests - vestiges of a vanishing ecosystem in the Andes. Ecotropica, 8, pp. 111-123, 2002.

[40] Hosonuma, N., et al., An assessment of deforestation and forest degradation drivers in developing countries. Environ. Res. Lett., 7(044009), 2012.

[41] Geist, H.J. \& Lambin, E.F., Proximate causes and underlying driving forces of tropical deforestation tropical forests are disappearing as the result of many pressures, both local and regional, acting in various combinations in different geographical locations. Bioscience, 52, pp. 143-150, 2002. 